\title{
HUBUNGAN PENYAKIT JANTUNG BAWAAN DENGAN STATUS GIZI PADA ANAK DI RSUP PROF. DR. R. D. KANDOU MANADO TAHUN 2009-2013
}

\author{
${ }^{1}$ Pingkan Putri Maramis \\ ${ }^{2}$ Erling David Kaunang \\ ${ }^{2}$ Johnny Rompis \\ ${ }^{1}$ Kandidat Skripsi Fakultas Kedokteran Universitas Sam Ratulangi Manado
${ }^{2}$ Bagian Ilmu Kesehatan Anak Fakultas Kedokteran Universitas Sam Ratulangi Manado
}

\begin{abstract}
Congenital heart disease (CHD) is a congenital disorder that is common, with the incidence of $30 \%$ of all congenital abnormalities. The incidence of congenital heart disease in developed countries and developing countries ranges from 6-10 cases per 1000 live births, with an average of 8 per 1,000 live births. Nutritional status of a person is basically the person's state of health as a reflection of food consumption and use by the body. Many factors influence the nutritional status of infants and children with congenital heart disease. Nutritional status of patients with CHD is influenced nutrient inputs, energy requirements, dietary components. Objective: Knowing the relationship between congenital heart disease with nutritional status in children. Methods: This study is a retrospective analytic approach. The subjects were all children with congenital heart disease who are hospitalized in the Section of Child Health, Prof. Dr. R. D. Kandou Manado in 2009-2013. The data taken in the form of data gender of the child, the child's age, weight and height as well as nutritional status. Data analysis was performed by Chi-Square test. Result: The number of respondents were 53 children, 34 boys and 19 girls. Types of congenital heart disease is the most common type of Atrial Septal Defect. Most people with experience malnutrition (54.7\%), followed by poor nutrition (37.8\%) and good nutrition (7.5\%). With Chi-Square test of the hypothesis, obtained p-value $=0.045$ which suggests a link between congenital heart disease with nutritional status in children. Conclusion: Based on the results of congenital heart disease associated with poor nutritional status in children or less.
\end{abstract}

Keyword: congenital heart disease, nutritional status.

\begin{abstract}
Abstrak: Penyakit jantung bawaan (PJB) merupakan kelainan bawaan yang sering dijumpai, dengan angka kejadian $30 \%$ dari seluruh kelainan bawaan. ${ }^{1}$ Insiden PJB dinegara maju maupun negara berkembang berkisar 6 - 10 kasus per 1000 kelahiran hidup, dengan rata-rata 8 per 1000 kelahiran hidup. Status gizi seseorang pada dasarnya merupakan keadaan kesehatan orang tersebut sebagai refleksi dari konsumsi pangan serta penggunaannya oleh tubuh. ${ }^{1}$ Banyak faktor ikut mempengaruhi status gizi pada bayi dan anak dengan PJB. ${ }^{2}$ Status gizi penderita PJB dipengaruhi masukan nutrien, kebutuhan energi, komponen diet. ${ }^{1}$ Tujuan: Mengetahui adanya hubungan antara penyakit jantung bawaan dengan status gizi pada anak. Metode: Penelitian ini bersifat analitik dengan pendekatan retrospektif. Subjek penelitian adalah semua anak dengan penyakit jantung bawaan yang dirawat inap di Bagian Ilmu Kesehatan Anak RSUP Prof. Dr. R. D. Kandou Manado tahun 2009-2013. Data yang diambil berupa data jenis kelamin anak, umur anak, berat badan dan tinggi badan anak serta status gizi. Analisis data dilakukan dengan uji Chi-Square. Hasil: Jumlah responden sebanyak 53 anak, 34 anak laki-laki dan 19 anak perempuan. Jenis PJB yang paling banyak diderita adalah jenis Atrial Septal Defect. Kebanyakan penderita mengalami gizi kurang (54.7\%), diikuti dengan gizi buruk (37.8\%) dan gizi baik (7.5\%). Dengan uji hipotesis Chi-Square, didapatkan $p$-value $=0.045$ yang menunjukkan adanya hubungan antara penyakit jantung bawaan dengan status gizi pada anak. Simpulan: Berdasarkan hasil penelitian didapatkan penyakit jantung bawaan berhubungan dengan status gizi buruk atau kurang pada anak.
\end{abstract}

Kata Kunci: penyakit jantung bawaan, status gizi. 
Angka kejadian PJB di Indonesia adalah 8 tiap 1000 kelahiran hidup. Berdasarkan profil Kesehatan Indonesia 2008, angka kejadian Penyakit Jantung dan Pembuluh Darah di Indonesia cenderung meningkat dan dapat menyebabkan gangguan tumbuh kembang, kecacatan dan kematian. ${ }^{3}$ Menurut PERKI (Perhimpunan Dokter Spesialis Kardiovaskuler Indonesia), penyakit jantung bawaan menempati peringkat pertama diantara penyakit-penyakit lain yang menyerang bayi. ${ }^{4}$

Malnutrisi pada anak dengan PJB dapat meningkatkan morbiditas dan mortalitas. Hal ini disebabkan oleh karena anak tersebut akan lebih sering terkena penyakit, ketidakberhasilan operasi, gangguan pertumbuhan dan peningkatan resiko kematian. ${ }^{5}$ Walaupun anak dengan PJB yang tidak begitu parah biasanya memiliki pertumbuhan dan perkembangan yang normal, tetapi dengan adanya penyakit jantung yang dimiliknya mereka memiliki risiko yang besar untuk jatuh dalam keadaan nutrisi buruk, anak dengan PJB sering menunjukkan pencapaian berat badan yang tidak baik dan keterlambatan pertumbuhan. ${ }^{6}$

Faktor-faktor yang mempengaruhi rendahnya pemasukan kalori pada PJB kemungkinan disebabkan oleh hilangnya nafsu makan, sesak napas, kelelahan, muntah yang berlebihan, infeksi saluran napas, anoreksia dan asidosis. Juga dapat disebabkan karena ketidakmampuan tubuh menggunakan nutrisi untuk pertumbuhan karena malabsorbsi, dan atau berhubungan dengan meningkatnya kebutuhan nutrisi. ${ }^{7}$

\section{PENYAKIT JANTUNG BAWAAN}

Penyakit jantung bawaan (PJB) adalah permasalahan pada struktur jantung yang tampak setelah kelahiran. Kelainan ini dapat melibatkan bagian dalam dinding jantung, klep di dalam jantung, atau arteri dan vena yang membawa darah ke jantung atau ke seluruh tubuh. $^{8}$

PJB yang berat bisa dikenali saat kehamilan atau segera setelah kelahiran. PJB yang ringan sering tidak menampakkan gejala, dan diagnosisnya didasarkan pada peme-riksaan fisik dan tes khusus untuk alasan yang lain.Gejala dan tanda PJB yang mungkin terlihat pada bayi atau anak-anak antara lain: bernafas cepat, sianosis (suatu warna kebiru-biruan pada kulit, bibir, dan kuku jari tangan), cepat lelah, peredaran darah yang buruk, dan nafsu makan berkurang. ${ }^{11,13}$

\section{PJB NON - SIANOTIK}

\section{PJB non-sianotik dengan pirau kiri ke kanan}

\section{Defek Septum Ventrikel (DSV)}

DSV merupakan PJB yang sering ditemukan, yaitu sekitar 30\% dari semua PJB. ${ }^{9,10}$ Defek Septum Ventrikel (DSV) adalah kelainan jantung berupa lubang pada sekat antar bilik jantung, menyebabkan kebocoran aliran darah pada bilik kiri dan kanan jantung. ${ }^{11,12}$ Hal ini mengakibatkan sebagian darah kaya oksigen kembali ke paru-paru, sehingga menghalangi darah rendah oksigen memasuki paru-paru. ${ }^{12}$

\section{Defek Septum Atrium}

Defek Septum Atrium (DSA) adalah defek pada sekat yang memisahkan atrium kiri dan kanan. ${ }^{3}$ Secara anatomis defek ini dibagi menjadi defek septum atrium primum, sekundum, tipe sinus venosus, dan tipe sinus koronarius. ${ }^{3}$

\section{Duktus Arteriosus Persisten}

Duktus Arteriosus Persisten (DAP) disebabkan oleh duktus arteriosus yang tetap terbuka setelah bayi lahir. ${ }^{3}$ Jika duktus tetap terbuka setelah penurunan resistensi vaskular paru, maka darah aorta dapat bercampur ke darah arteri pulmonalis. ${ }^{12}$

\section{PJB tanpa pirau}

\section{Stenosis Pulmonal}

Pada stenosis pulmonalis (SP) terjadi obstruksi aliran keluar ventrikel kanan atau arteri pulmonalis dan cabang-cabangnya. Bayi dan anak dengan stenosis ringan umumnya asimptomatik dan tidak sianosis sedangkan neonatus dengan stenosis berat 
Maramis, Kaunang, Rompis; Hubungan Penyakit Jantung Bawaan dengan Status Gizi...

atau kritis akan terlihat takipneu dan sianosis. ${ }^{3}$

\section{Stenosis Aorta}

Stenosis Aorta (SA) merupakan penyempitan aorta yang dapat terjadi pada tingkat subvalvular, valvular, atau supravalvular. Kelainan ini mungkin tidak terdiagnosis pada masa anak-anak karena katub berfungsi normal. ${ }^{3}$ Bayi dengan Stenosis Aorta derajat berat akan timbul gagal jantung kongestif pada usia mingguminggu pertama atau bulan-bulan pertama kehidupannya. $^{9}$

\section{Koartasio Aorta}

Koartasio Aorta (KA) adalah penyempitan terlokalisasi pada aorta yang umumnya terjadi pada daerah duktus arteriosus. Tanda yang klasik pada kelainan ini adalah tidak terabanya nadi femoralis serta dorsalis pedis sedangkan nadi brakialis teraba normal. Koarktasio aorta pada anak besar seringkali asimtomatik. Sebagian besar dari pasien mengeluh sakit kepala, nyeri di tungkai dan kaki, atau terjadi epistaksis. ${ }^{9}$

\section{PJB SIANOTIK}

Manifestasi klinis pasien penyakit jantung bawaan sianotik sangat bervariasi. Sebagian pasien menunjukkan gejala sianosis akibat hipoksemia, dengan atau tanpa gagal jantung, sebagian mengalami syok, sebagian lagi tidak menunjukkan gejala dan pada auskultasi hanya terdengar bising saja. $^{13}$

\section{Penyakit jantung bawaan sianotik dengan aliran darah ke paru berkurang Tetralogi of Fallot ${ }^{14}$}

Tetralogi of Fallot (ToF) merupakan kombinasi 4 komponen, yaitu defek septum ventrikel, over-riding aorta, stenosis pulmonal serta hipertrofi ventrikel kanan. Komponen yang paling penting yang menentukan derajat beratnya penyakit adalah stenosis pulmonal bahkan dapat berupa atresia pulmonal.

\section{Atresia Pulmonal dengan Defek Septum Ventrikel $^{14}$}

Kelainan ini merupakan 20\% dari pasien dengan gejala menyerupai tetralogi Fallot dan merupakan penyebab penting sianosis pada neonatus. Darah dari ventrikel tidak dapat menuju a. pulmonalis dan semua darah dari ventrikel kanan akan masuk ke aorta.

\section{Atresia Pulmonal Tanpa Defek Septum Ventrikel $^{14}$}

Dari atrium kanan darah menuju ke atrium kiri melalui defek septum atrium atau foramen ovale. Satu - satunya jalan darah ke paru adalah melalui duktus arteriosus atau sirkulasi bronkial.

\section{Atresia Trikuspid}

Pada defek ini, tidak terdapat aliran dari atrium kanan menuju ventrikel kanan sehingga seluruh aliran balik vena sistemik masuk ke bagian kiri jantung melalui foramen ovale atau jika terdapat defek pada septum atrium. ${ }^{12}$ Insidensi AT diperkirakan 1 per 10.000 kelahiran hidup dengan estimasi prevalensi AT dari seluruh kasus PJB adalah 2.9\% dari autopsi dan 1.4\% dari penegakkan diagnosis setelah dilakukan pemeriksaan berulang. ${ }^{15}$ Apabila aliran darah paru berkurang maka pasien akan tampak sianotik; semakin sedikit darah ke paru maka semakin jelas sianosis yang terjadi. $^{14}$

\section{Anomali Ebstein}

Anomali Ebstein (AE) adalah suatu kelainan jantung bawaan berupa malformasi katup trikuspidalis (KT), ditandai oleh letak daun posterior dan daun septum KT berpindah tempat ke arah lebih rendah ke dalam ventrikel kanan sehingga ruangan ventrikel kanan menjadi kecil, ruangan atrium kanan menjadi sangat besar karena bergabung dengan ruang atrialisasi ventrikel kanan , dan KT menjadi tidak kompeten. ${ }^{16,17}$ 
Penyakit jantung bawaan sianotik dengan aliran darah ke paru yang meningkat

Kondisi ini disebut admixture lesions karena terdapatnya pirau dari kiri ke kanan serta sebaliknya. Sehingga, terdapat suatu ruang tempat alir balik paru dan alir balik sistemik yang bercampur yang kemudian diteruskan ke pembuluh darah besar. $^{14}$ Termasuk dalam kelompok ini adalah:

\section{Transposisi Arteri Besar}

Pada TAB terjadi perubahan tempat keluarnya arteri besar, yakni aorta keluar dari ventrikel kanan dan terletak di sebelah anterior arteri pulmonalis, sedangkan arteri pulmonalis keluar dari ventrikel kiri, terletak posterior terhadap aorta. Akibatnya, aorta menerima darah vena sistemik dari vena kava, atrium kanan, ventrikel kanan, dan darah diteruskan ke sirkulasi sistemik serta darah dari vena pulmonalis dialirkan ke atrium kiri, ventrikel kiri, dan diteruskan ke arteri pulmonalis dan paru. Dengan demikian, maka kedua sirkulasi sistemik serta paru tersebut terpisah dan kehidupan hanya dapat berlangsung apabila ada komunikasi antara 2 sirkulasi ini. ${ }^{18,19}$

\section{Trunkus Arteriosus $^{9}$}

Trunkus arteriosus ditandai oleh keluarnya pembuluh tunggal dari jantung yang menampung aliran darah dari kedua ventrikel, yang memasok darah sistemik, paru dan koroner.

\section{Ventrikel Tunggal $^{14}$}

Dasar anatomi kelainan ini adalah terdapatnya suatu ventrikel yang besar yang mempunyai kedua katup atrioventrikular.

Sebagian pasien tidak mengalami sianosis berat, namun terdapat dipsnue, takipnue, dengan penurunan toleransi latihan yang menandakan terjadinya gagal jantung.

\section{Anomali Total Drainase Vena Pulmonalis ${ }^{14}$}

Penyakit ini adalah jenis penyakit jantung bawaan yang sangat jarang ditemukan. Pada kelainan ini drainase keempat vena pulmonalis yang seharusnya ke atrium kiri, secara abnormal langsung atau tidak langsung bermuara ke dalam atrium kanan.

\section{STATUS GIZI}

Status gizi didefinisikan sebagai ukuran keberhasilan dalam pemenuhan nutrisi untuk anak, yang diindikasikan oleh berat badan dan tinggi badan anak. Status gizi juga diartikan sebagai status kesehatan yang dihasilkan oleh keseimbangan antara kebutuhan dan masukan nutrien.

\section{Faktor-faktor yang mempengaruhi status gizi $^{20}$}

\section{Langsung}

Penyebab langsung timbulnya gizi kurang pada anak adalah konsumsi pangan dan penyakit.

\section{Tidak langsung}

a. Pola Asuh gizi

Pola asuh gizi merupakan praktik dirumah tangga yang diwujudkan dengan tersedianya pangan dan perawatan kesehatan untuk kelangsungan hidup, pertumbuhan dan perkembangan anak.

b. Psikologi

Psikologi seseorang dapat mempengaruhi pola makan.

c. Genetik

Genetik menjadi salah satu faktor dari status gizi karena pada anak dengan status gizi lebih atau obesitas besar kemungkinan dipengaruhi oleh orang tuanya (herediter).

d. Pelayanan kesehatan

Pelayanan kesehatan ini meliputi imunisasi, pemeriksaan kehamilan, pertolongan persalinan, penimbangan berat badan anak, sarana lain seperti keberadaan posyandu dan puskesmas, praktik bidan, dokter dan rumah sakit.

\section{Penilaian Status Gizi}

\section{Metode antropometri}

Antropometri adalah pengukuran dimensi tubuh manusia dalam hal ini 
dimensi tulang, otot dan jaringan lemak.

Pengukuran antropometri yang sering digunakan adalah tinggi atau panjang badan dan berat badan. Pengukuran tersebut dapat dilakukan dengan mudah dan cepat juga akurat. Tujuan utama yang hendak dicapai dalam pemeriksaan antropometris adalah besaran komposisi tubuh yang dapat dijadikan isyarat dini perubahan status gizi. $^{21}$ Ada tiga cara penyajian distribusi indeks antropometri: yaitu persen terhadap median, persentil dan z-score median. Hasil perhitungan indeks antropometri berdasarkan persen terhadap median maupun persentil dan z-score dikaitkan dengan salah satu atau beberapa batas ambang (cut-off point) dan perwujudannya disebut sebagai kategori status gizi. $^{21}$

\section{Berat badan}

Berat badan dipakai sebagai indikator terbaik saat ini untuk mengetahui keadaan gizi dan tumbuh kembang anak, sensitif terhadap perubahan sedikit saja, pengukuran objektif dan dapat diulangi, dapat digunakan timbangan apa saja yang relatif murah, mudah dan tidak memerlukan banyak waktu. Kerugiaannya, indikator berat ini tidak sensitif terhadap proporsi tubuh, misalnya pendek, gemuk atau tinggi kurus. Berat badan digunakan untuk mengevaluasi keseimbangan asupan makanan dengan energi yang dikeluarkan untuk aktivitas. ${ }^{22}$

\section{Panjang badan/tinggi badan}

Pengukuran tinggi badan diperlukan sebagai parameter status gizi berdasarkan berat badan terhadap tinggi badan. ${ }^{22}$

\section{Z-score}

Nilai pasti dari Z-score dapat dihitung dengan menggunakan referensi standart deviasi dari NCHS/WHO sebagai referensi populasi yang dikeluarkan oleh $W H O .^{23}$

Penilaian status gizi berdasarkan Zscore dilakukan dengan cara melihat distribusi normal nilai pertumbuhan orang yang diperiksa. Angka ini melukiskan jarak nilai baku median dalam urutan simpang baku. Nilai Z-score diperoleh dari hasil pembagian antara ukuran antropometris orang yang diperiksa dengan nilai baku acuan. $^{21}$

\section{Berat badan menurut umur $(B B / U)^{23}$}

Dalam keadaan normal, dimana keadaan kesehatan baik dan keseimbangan antara masukan dan kecukupan zat-zat gizi terjamin, berat badan berkembang mengikuti pertambahan umur. Sebaliknya dalam keadaan normal, terdapat 2 kemungkinan perkembangan berat badan: berkembang dengan cepat atau lebih lambat dari keadaan normal. Berdasarkan sifat-sifat ini maka indeks berat badan menurut umur digunakan sebagai salah satu indikator status gizi, dan karena sifat berat badan yang labil, maka indeks BB/U lebih menggambarkan status gizi seseorang pada saat ini.

\section{Berat badan menurut tinggi badan $(B B / T B)^{23}$}

Berat badan memiliki hubungan linier dengan tinggi badan. Dalam keadaan normal perkembangan berat badan akan searah dengan pertambahan tinggi badan dengan percepatan tertentu, Indeks tunggal $\mathrm{BB} / \mathrm{TB}$ merupakan indikator yang baik untuk menyatakan status gizi saat ini seperti halnya $\mathrm{BB} / \mathrm{U}$, digunakan bila data umur yang akurat sulit diperoleh. Karena itu indeks BB/TB dapat memberikan gambaran proporsi berat badan relatif terhadap tinggi badan, maka indeks ini merupakan pula indikator kekurusan. ${ }^{1}$

\section{Tinggi badan menurut umur $(\mathrm{TB} / \mathrm{U})^{23}$}

Dalam keadaan normal, tinggi badan tumbuh bersamaan dengan pertambahan umur. Pertumbuhan tinggi badan tidak seperti berat badan relatif kurang sensitif terhadap defisiensi gizi jangka pendek. Pengaruh defisiensi zat gizi terhadap tinggi badan baru tampak pada saat yang cukup lama. Indeks TB/U lebih menggambarkan status gizi masa lalu. Bila tinggi badan menurut umur berada dibawah standar normal dikatakan mengalami malnutrisi kronis. TB/U adalah pencapaian pertumbuhan linier yang dapat digunakan 
sebagai indeks status gizi di masa lalu atau status gisi sekarang.

\section{Indeks Massa Tubuh (IMT) ${ }^{23}$}

IMT adalah angka yang didapatkan dari hasil perhitungan berat badan dan tinggi badan pada anak. IMT adalah indikator yang dapat dipakai untuk menilai lemak tubuh untuk kebanyakan anak dan remaja. IMT tidak mengukur lemak tubuh secara langsung, tetapi penelitian terdahulu mengatakan bahwa IMT berkorelasi dengan pengukuran lemak tubuh secara langsung. IMT dapat dijadikan alternatif untuk pengukuran lemak tubuh. Untuk anak dan remaja,

\section{HUBUNGAN PENYAKIT JANTUNG BAWAAN DENGAN STATUS GIZI PADA ANAK}

Status gizi adalah ekspresi dari keadaan keseimbangan dalam bentuk variabel tertentu atau dapat dikatakan bahwa status gizi merupakan indikator baik-buruknya penyediaan makanan sehari-hari. Status gizi yang baik diperlukan untuk mempertahankan derajat kebugaran dan kesehatan, serta membantu pertumbuhan bagi anak. ${ }^{22}$

Banyak faktor ikut mempengaruhi status gizi pada bayi dan anak dengan PJB. ${ }^{2}$ Status gizi penderita penyakit jantung bawaan dipengaruhi masukan nutrien, kebutuhan energi, komponen diet. Kondisi prenatal seperti gangguan pertumbuhan intrauterine, kromosom yang abnormal contohnya trisomi kromosom 18 dan 21, dan malformasi nonkardiak yang lain seperti palato schizis dapat berpengaruh pada nutrisi yang masuk, pertumbuhan dan perkembangan. $^{2}$

Walaupun anak dengan PJB yang tidak begitu parah biasanya memiliki pertumbuhan dan perkembangan yang normal, tetapi dengan adanya penyakit jantung yang dimiliknya mereka memiliki risiko yang besar untuk jatuh dalam keadaan nutrisi buruk, anak dengan PJB sering menunjukkan pencapaian berat badan yang tidak baik dan keterlambatan pertumbuhan. Malnutrisi pada penyakit jantung menyebabkan kegagalan perkembangan karena asupan nutrisi yang tidak adekuat dan gangguan absorbsi. $^{6}$

\section{METODE PENELITIAN}

Penelitian ini bersifat analitik dengan pendekatan retrospektif. Subjek penelitian adalah semua anak dengan penyakit jantung bawaan yang dirawat inap di Bagian Ilmu Kesehatan Anak RSUP Prof. Dr. R. D. Kandou Manado tahun 2009-2013. Data yang diambil berupa data jenis kelamin anak, umur anak, berat badan dan tinggi badan anak serta status gizi. Analisis data dilakukan dengan uji Chi-Square.

\section{HASIL DAN PEMBAHASAN}

Dari penelitian yang dilakukan selama bulan November 2013 sampai Januari 2014 didapatkan total sampel berjumlah 53 anak penderita penyakit jantung bawaan di RSUP Prof. Dr. R. D. Kandou Manado yang sesuai kriteria inklusi peneliti didapatkan 34 anak berjenis kelamin laki-laki dan 19 anak berjenis kelamin perempuan.

Didapatkan penderita yang terbanyak adalah berumur 1-6 tahun.

Didapatkan juga PJB jenis ASD adalah yang terbanyak $(34,0 \%)$ dan diikuti oleh jenis VSD (28,3\%). Tidak terdapat perbedaan yang bermakna di antara kedua jenis PJB tersebut.

Distribusi penderita PJB berdasarkan status gizi didapatkan bahwa pasien PJB lebih banyak mengalami gizi kurang.

Juga didapatkan bahwa hubungan penyakit jantung bawaan dengan status gizi pada anak di RSUP Prof. Dr. R.D. Kandou menunjukkan p value sebesar 0,045 angka ini bersifat bermakna tetapi tidak terlalu signifikan $(\mathrm{p}<0.05)$. Nilai ini menunjukkan adanya hubungan antara penyakit jantung bawaan dengan status gizi pada anak.

Status gizi penderita penyakit jantung bawaan dipengaruhi masukan nutrien, kebutuhan energi, komponen diet. ${ }^{1}$ Satu tahun pertama kelahiran adalah waktu di mana pertumbuhan paling cepat terjadi, ${ }^{24}$ pertumbuhan ini dipengaruhi oleh asupan nutrisi yang diterima oleh bayi tersebut. 
Karena itu, asupan makanan yang diterima oleh bayi dengan PJB selama setahun pertama kehidupan merupakan hal yang penting bagi pertumbuhan dimana akan mempengaruhi status gizi mereka.

\section{SIMPULAN}

Berdasarkan hasil penelitian dan pembahasan, didapatkan kesimpulan bahwa penyakit jantung bawaan berhubungan dengan status gizi buruk atau kurang pada anak.

\section{SARAN}

1. Status gizi pada anak dengan penyakit jantung bawaan adalah sesuatu yang perlu mendapatkan perhatian, baik oleh orang tua pasien maupun oleh petugas medis.

2. Asupan makanan yang baik dan seimbang perlu diberikan pada anak dengan penyakit jantung bawaan.

3. Sebaiknya dilakukan penyuluhan dan pendampingan mengenai pentingnya kecukupan gizi kepada orang tua yang mempunyai anak dengan penyakit jantung bawaan.

\section{DAFTAR PUSTAKA}

1. Wisnuwardhana M. Manfaat Pemberian Diet Terhadap Pertumbuhan Pada Anak dengan Penyakit Jantung Bawaan [Disertasi]. Semarang: Universitas Diponegoro; 2006

2. Lewis A, Hsieh V. Congenital Heart Disease and Lipid Disorders in Chidren. Pediatric Nutrition. 2nd Edition. 2005.

3. Roebiono PS. Diagnosis dan Tatalaksana Penyakit Jantung Bawaan [internet]. Diunduh dari: http://repository.ui.ac.id/ contents/koleksi/11/68321669235fd5a14595 241e85893e6bbb8907f2.pdf.

4. Penyakit Jantung Bawaan, Angka Tinggi dengan tenaga terbatas [internet]. 2010. Diunduh dari: http://www.inaheart.org/ index.php/public/information/news.detail/12

5. Okoromah CAN, Ekure EN, Lesi FEA, Okunowo WO, Tijani BO, Okeiyi JC. Prevalence, Profile and Predirectors of Malnutrition in Children with Congenital
Heart Defects: a Case-Control Observational Study. Arch Dis Child. 2011 April 1; 96 (4): 354-60. Diunduh dari: http://www.ncbi. nlm.nih.gov/pubmed/21266339

6. Rosenthal A. Nutritional Considerations in the Prognosis and Treatment of Children with Congenital Heart Disease. In : Suskind RM, Suskind MM, editors. Textbook of Pediatric Nutrition. 2nd ed. New York: Raven Press; 1992.

7. Forchielli ML, McColl R, Walker WA, Lo C. Children with Congenital Heart Disease : A Nutritional Challenge. Nutrition Grand Rounds. 1994 Oct: 348-53.

8. Congenital heart defects [internet]. 2011 [cited 2011 Sept 16] Diunduh dari: http://www.medicinet.com/congenital_heart _disease/article.htm

9. Sastroasmoro S, Madiyono B. Epidemiologi dan Etiologi Penyakit Jantung Bawaan. Dalam: Sastroasmoro S, Madiyono B, penyunting. Buku Ajar Kardiologi Anak. Binarupa Aksara. 1994: h.165-7.

10. Hull A. Children with Chronic Diseases and Developmental Disorders: Prevention, Assesment and Treatment. Oxford University Press. 1993: h. 279-86.

11. Heart attack symptoms and early warning signs [internet]. 2011 Feb 09. Diunduh dari: http://www.ilunifk83.com/t126p630-heartattack-symptoms-and-early-warning-signs pada tanggal 28 Sept. 2013

12. Bernstein, Daniel. The Cardiovascular System. Dalam: Kliegman, Robert M. et al. Nelson Textbook of Pediatrics $18^{\text {th }}$ Edition. Saunders Elsevier, Philadelphia. 2007: h.1828-1928

13. Juliana W. Kelainan jantung bawaan pada anak [internet]. 2011 July 18]. Diunduh dari: http://www.analisadaily.com/news/read/201 1/07/18/5298/kelainan_jantung_bawaan_pa da_anak/ pada tanggal 13 Sept. 2013.

14. Prasodo AM, Penyakit Jantung Bawaan Sianotik. Dalam: Sastroasmoro S, Madiyono B, editor. Buku Ajar Kardiologi Anak. Binarupa Aksara. 1994: h. 234-77

15. Rao PS. Tricuspid Atresia. 2009. Diunduh dari: http//emedicine.medscape.com/article/ 900832-overview

16. Behrman RE, Vaughn VC. Ebstein Disease. The Cardiovascular System. Dalam: Behrman RE, Vaughn VC, eds. Nelson Textbook of Pediatrics (13 ${ }^{\text {th }}$ ed). Philadelphia, London, Toronto: WB Saunders Co. 2004: h. 1532-4. 
17. Yetman AT, Freedom RM, McCrindle BW. Outcome in Cyanotic Neonaties with Ebsteins Anomaly. AM. J. Cardiol. 1998; 81; h.749-54

18. Derrick G, Cullen S. Transposition of the Great Arteries. Curr Treat. Opt. Cardiovascular Med. 2000: 2: 499-506.

19. Salih C, Brizard C, Penny DJ, Anderson RH. Transposition. Dalam: Anderson RH, Baker EJ, Penny D, Redington AN, Rigby ML, Wernovsky G, editor. Paediatric cardiology. Edisi ke-3. Philadelphia: Churchill Livingstone Elsevier; 2010. h. 795-817.

20. Soekirman. Ilmu Gizi dan Aplikasinya Untuk Keluarga dan Masyarakat. Jakarta: Direktorat Jenderal Pendidikan Tinggi, Depdiknas; 2001.
21. MB Arisman. Gizi dalam Daur Kehidupan: Buku Ajar Ilmu Gizi (Edisi 2). Jakarta: EGC; 2008.

22. Irianto DP. Panduan Gizi Lengkap Keluarga dan Olahragawan. Yogyakarta: Penerbit Andi; 2007.

23. Gibson RS. Anthropometric Assessment of Body Size. Priciple of Nutritional Assessment (2nd ed). Oxford University Press; 2005.

24. Irving Sharon Y. Patterns of Weight Change in Infants with Congenital Heart Disease Following Neonatal Surgery: Potential Predictors of Growth Failure [dissertation]. Pennsylvania (United States) : University of Pennsylvania; 2011. 